\title{
Article
}

\section{Self-metathesis of 1-butene to ethene and hexene over molybdenum-based heterogeneous catalysts}

\author{
Ce Guo a,b, Xiujie Li a,\#, Xiangxue Zhu a , Weifeng Chu a,b, Shenglin Liu a, Yuzhong Wang a, Peng Zengc, \\ Shujing Guo ${ }^{\mathrm{d}}$, Longya $\mathrm{Xu}^{\mathrm{a}}$,* \\ a Dalian National Laboratory for Clean Energy, Dalian Institute of Chemical Physics, Chinese Academy of Sciences, Dalian 116023, Liaoning, China \\ b University of Chinese Academy of Sciences, Beijing 100049, China \\ c China Huanqiu Contracting and Engineering Corporation, Fushun 113006, Liaoning, China \\ d Shaanxi Yanchang Petroleum (Group) Co. Ltd., Yan'an 716000, Shaanxi, China
}

\section{A R T I C L E I N F}

\section{Article history:}

Received 11 September 2017

Accepted 16 September 2017

Published 5 January2018

\section{Keywords:}

1-Butene

Self-metathesis

Molybdenum

Ethene

Hexene

\begin{abstract}
A B S T R A C T
A novel route involving self-metathesis of 1-butene under mild conditions that gave high yields of ethene and hexene was proposed. The results of thermodynamic analysis revealed that the Gibbs energy of the target Metathesis I reaction (1-butene $\rightarrow$ ethene +3 -hexene) was much higher than that of the main side Metathesis II (1-butene +2 -butene $\rightarrow$ propene +2 -pentene). Suppression of 1-butene double-bond isomerization was the key step to increase the selectivity for the target olefin in the reaction network. The relationship between the catalytic performance and support nature was investigated in detail. On basis of $\mathrm{H}_{2}$-TPR, UV-Vis spectra and HRTEM results, an alumina $\left(\mathrm{Al}_{2} \mathrm{O}_{3}\right)$ support with large surface area was beneficial for the dispersion of molybdenum (Mo) species. Both suitable acidity and sufficient Mo dispersion were important to selectively promote the self-metathesis reaction of 1-butene. On the optimal $6 \mathrm{Mo} / \mathrm{Al}_{2} \mathrm{O}_{3}$ catalyst, 1-butene conversion reached $47 \%$ and ethene selectivity was as high as $42 \%$ on the premise of good catalytic stability $\left(80^{\circ} \mathrm{C}, 1.0 \mathrm{MPa}, 3 \mathrm{~h}^{-1}\right)$.
\end{abstract}

(C) 2018, Dalian Institute of Chemical Physics, Chinese Academy of Sciences. Published by Elsevier B.V. All rights reserved.

\section{Introduction}

During the past few years, olefin metathesis reactions have opened up many new industrial routes to important petrochemicals, polymers, and specialty chemicals [1,2]. Olefin metathesis is a powerful carbon-carbon bond rearrangement reaction in which the unsaturated carbon-carbon bonds can be redistributed in the presence of a catalyst. This route has been proved effective to produce value-added olefins according to market demand. Typical examples are the self-metathesis reac- tion of propene [3] and its reverse reaction (metathesis of ethene and 2-butene to propene) [4-6]. Besides, much attention has been paid to the development of metathesis catalysts from fundamental research to commercial application [7].

The increasing demand for propene has led to propene synthesis routes being focused on during the last few years [8-10]. To date, several olefin metathesis reaction routes using $\mathrm{C}_{4}$ olefins as raw materials have been developed, including self-metathesis of 1-butene [11-13], cross-metathesis of ethene and 2-butene [14-17] or 1-butene [18], and metathesis of

\footnotetext{
* Corresponding author. Tel/Fax: +86-411-84379279; E-mail: lyxu@dicp.ac.cn

\# Corresponding author. Tel/Fax: +86-411-84379279; E-mail: xiujieli@dicp.ac.cn

This work was supported by the National Natural Science Foundation of China (21773233) and the Natural Science Foundation of Liaoning Province (201602740).

DOI: 10.1016/S1872-2067(17)62918-8 | http://www.sciencedirect.com/science/journal/18722067 | Chin. J. Catal., Vol. 39, No. 1, January 2018
} 
2-butene [19]. In the context of declining international oil supply and the emergence of shale gas, the price of propene is volatile and sometimes falls below than that of ethene. On basis of surplus $\mathrm{C}_{4}$ olefins, self-metathesis of 1-butene to ethene and 3-hexene provides a promising route to produce value-added olefins. Here, 3-hexene could be further isomerized to 1-hexene, which is an important comonomer for the production of linear low-density polyethylene and high-density polyethylene. However, few articles on 1-butene self-metathesis have been reported, and only a few patents have been disclosed [20-22].

In this work, we present a novel route to produce ethene and hexene by the self-metathesis reaction of 1-butene. In the complicated reaction network, metathesis of 1-butene and 2-butene to propene is demonstrated to be the main side reaction. Isomerization of the 1-butene double bond is the main step determining target olefin selectivity. Consequently, the major objective of the present study is to find a catalyst suitable for the 1-butene self-metathesis reaction. The factors that influence the product distribution in the metathesis reaction are considered.

\section{Experimental}

\subsection{Catalyst preparation}

Na-type mordenite zeolite and $\mathrm{Al}_{2} \mathrm{O}_{3}$ composite supports were prepared by extruding a mixture of $\mathrm{Al}_{2} \mathrm{O}_{3}$ (prepared from pseudo-boehmite) and the Na-type mordenite zeolite $(\mathrm{Si} / \mathrm{Al}=$ 20, Fushun Petroleum Company, China) into strips with a diameter of about $2 \mathrm{~mm}$. The H-type mordenite and $\mathrm{Al}_{2} \mathrm{O}_{3}$ composite supports were ion-exchanged with $0.8 \mathrm{~mol} / \mathrm{L} \mathrm{NH}_{4} \mathrm{NO}_{3}$ solution at $80{ }^{\circ} \mathrm{C}$ three times to replace $\mathrm{Na}^{+}$with $\mathrm{NH}_{4}{ }^{+}$, and then washed and dried. The H-type composite supports were obtained by calcination at $520{ }^{\circ} \mathrm{C}$ in air for $3 \mathrm{~h}$, ground and then passed through 20-40 mesh filters. The Na-type mordenite and $\mathrm{Al}_{2} \mathrm{O}_{3}$ composite supports are denoted as NaMOR- $x \mathrm{Al}_{2} \mathrm{O}_{3}$, while the $\mathrm{H}$-type mordenite and $\mathrm{Al}_{2} \mathrm{O}_{3}$ composite supports are labeled as HMOR- $x \mathrm{Al}_{2} \mathrm{O}_{3}$, where $x$ represents the weight percent of alumina. $\mathrm{Al}_{2} \mathrm{O}_{3}-x$ and $\mathrm{SiO}_{2}$ supports were provided by the Aluminum Corporation of China Limited, Shandong Branch. Catalysts labeled as $x \mathrm{Mo} / \mathrm{Al}_{2} \mathrm{O}_{3}-\mathrm{A}$ were prepared by incipient wetness impregnation using an aqueous solution of $\left(\mathrm{NH}_{4}\right)_{6} \mathrm{Mo}_{7} \mathrm{O}_{24} \cdot 4 \mathrm{H}_{2} \mathrm{O}$ and left at room temperature for $24 \mathrm{~h}$; here, $x$ indicates the weight percent of Mo in the catalysts. The catalysts were dried at $120^{\circ} \mathrm{C}$ for $2 \mathrm{~h}$ and finally calcined at 600 ${ }^{\circ} \mathrm{C}$ for $2 \mathrm{~h}$.

\subsection{Characterization}

Nitrogen $\left(\mathrm{N}_{2}\right)$ physisorption experiments were performed at $-196{ }^{\circ} \mathrm{C}$ on a Micromeritics ASAP 2020 instrument. Prior to analysis, samples were outgassed at $350{ }^{\circ} \mathrm{C}$ under a vacuum of $10^{-3} \mathrm{~Pa}$ for $8 \mathrm{~h}$. Specific surface area was calculated by the standard multipoint Brunauer-Emmett-Teller (BET) method with a $P / P_{0}$ range of $0.05-0.30$. Pore volume was determined by $\mathrm{N}_{2}$ adsorption at $P / P_{0}=0.995$.
Powder X-ray diffraction (XRD) patterns were collected on a PANalytical X'pert PRO diffractometer using $\mathrm{Cu} K_{\alpha}$ radiation at $40 \mathrm{kV}$ and $40 \mathrm{~mA}$. The chemical composition of samples was determined on a Philips Magix 601X X-ray fluorescence (XRF) spectrometer.

Temperature-programmed desorption of ammonia ( $\mathrm{NH}_{3}$-TPD) experiments were carried out in a quartz microreactor (i.d. $4 \mathrm{~mm}$ ), which was connected to an online gas chromatograph (Shimadzu GC-8A) equipped with a thermal conductivity detector (TCD). The TCD response was calibrated by doses containing known amounts of $\mathrm{NH}_{3}$. Typically, the sample $\left(140 \mathrm{mg}\right.$ ) was first pretreated at $605{ }^{\circ} \mathrm{C}$ for $0.5 \mathrm{~h}$ in helium with a flow rate of $25 \mathrm{~mL} / \mathrm{min}$, then cooled to $150{ }^{\circ} \mathrm{C}$ and saturated with $\mathrm{NH}_{3}$. Subsequently, $\mathrm{NH}_{3}$ was purged in a helium flow for a certain period at $150{ }^{\circ} \mathrm{C}$ until a stable baseline was obtained. The reactor temperature was raised from 150 to $605^{\circ} \mathrm{C}$ at a heating rate of $19.8^{\circ} \mathrm{C} / \mathrm{min}$.

Infrared (IR) spectra were recorded with a Bruker Vertex 70 IR spectrometer at $4-\mathrm{cm}^{-1}$ optical resolution. Prior to measurements, the samples were pressed into self-supporting wafers with a diameter of $1.3 \mathrm{~cm}$ and pre-treated in an IR cell at $450{ }^{\circ} \mathrm{C}$ for $1 \mathrm{~h}$ under $10^{-2} \mathrm{~Pa}$. The cell was cooled to room temperature to record the background spectra. Each sample was saturated with pyridine (Py) and then the excess Py was removed under vacuum at $150{ }^{\circ} \mathrm{C}$ for $0.5 \mathrm{~h}$. After cooling to room temperature again, the sample was subjected to IR measurements to quantify the amount of acid sites.

Temperature-programmed reduction of $\mathrm{H}_{2}\left(\mathrm{H}_{2}\right.$-TPR) experiments were carried out using a custom-made setup. Prior to measurements, each sample $(100 \mathrm{mg})$ was pretreated at 550 ${ }^{\circ} \mathrm{C}$ for $1 \mathrm{~h}$ under Ar flow to remove water and other contaminants and then cooled to $200{ }^{\circ} \mathrm{C}$. The reduction step was carried out in a mixture flow of $10 \% \mathrm{H}_{2} / 90 \%$ Ar from 200 to 900 ${ }^{\circ} \mathrm{C}$ at a heating rate of $15^{\circ} \mathrm{C} / \mathrm{min}$. The $\mathrm{H}_{2}$ signal was monitored online by a TCD detector.

Ultraviolet-visible (UV-Vis) spectra were recorded in a diffuse reflectance mode with a JASCO V-550 spectrometer at room temperature in the range of $200-600 \mathrm{~nm}$ at a rate of 40 $\mathrm{nm} / \mathrm{min}$.

High-resolution transmission electron microscopy (HRTEM) images were recorded on a JEM-2100 transmission electron microscope (JEOL, Japan) with an accelerating voltage of 200 $\mathrm{kV}$.

\subsection{Catalyst evaluation}

The self-metathesis of 1-butene was carried out in a fixed bed microreactor with a length of $320 \mathrm{~mm}$ and diameter of 7 $\mathrm{mm}$. The catalyst $(1 \mathrm{~g})$ was located in the middle part of the fixed-bed reactor. The catalyst was activated in situ at $500{ }^{\circ} \mathrm{C}$ for $2 \mathrm{~h}$ in $\mathrm{N}_{2}$ flow before the reaction. The reaction products were analyzed by an online Agilent 7890B gas chromatograph (GC) equipped with a flame ionization detector and $\mathrm{Al}_{2} \mathrm{O}_{3}$ capillary column.

The GC results indicated that cis-, trans-2-pentene and cis-, trans-3-hexene were the major products with $\mathrm{C}_{5}$ and $\mathrm{C}_{6}$ structures, respectively. To simplify treatment, we denoted products 
with the same carbon number as $\mathrm{C}_{n}^{=}$, where $n$ represents carbon number.

Conversion $\left(X\left(1-\mathrm{C}_{4}^{=}\right)\right)$and selectivity $\left(S\left(\mathrm{C}_{n}^{=}\right)\right)$were calculated using the following equations:

$$
\begin{gathered}
X\left(1-\mathrm{C}_{4}^{=}\right)=\left(\left[1-\mathrm{C}_{4}^{=}\right]_{\mathrm{F}}-\left[1-\mathrm{C}_{4}^{=}\right]_{\mathrm{p}}\right) /\left[1-\mathrm{C}_{4}^{=}\right]_{\mathrm{F}} \times 100 \% \\
S\left(\mathrm{C}_{n}^{=}\right)=\left(\left[\mathrm{C}_{n}^{=}\right]_{\mathrm{p}} / n\right) /\left(\sum\left[\mathrm{C}_{n}^{=}\right]_{\mathrm{p}} / n\right)
\end{gathered}
$$

For simplicity, $\left[1-\mathrm{C}_{4}^{=}\right]_{\mathrm{F}}$ and $\left[1-\mathrm{C}_{4}^{=}\right]_{\mathrm{p}}$ represent the weight percent of the component in the feed gas and product, respectively; $\left[\mathrm{C}_{n}^{=}\right] \mathrm{p}$ is the weight percent of product with carbon number $n$.

\subsection{Thermodynamic analysis}

The Gibbs free energy change is an important parameter in thermodynamic analysis. Thermodynamic data were obtained from the relevant thermodynamic manual. The correlation for the Gibbs energy of formation was a series expansion in temperature [23],

$$
\Delta_{\mathrm{f}} G(T)=a+b \times T+c \times T^{2}
$$

$\Delta_{\mathrm{f}} G$ is the Gibbs energy of formation of an ideal gas, $\mathrm{kJ} / \mathrm{mol}$; $a, b$, and $c$ are regression coefficients for chemical compounds; and $T$ is temperature, $\mathrm{K}$. The Gibbs energy change for the reaction $\Delta_{\mathrm{r}} G$ was calculated by Eq. (2).

$$
\Delta_{\mathrm{r}} G=\sum\left(v \Delta_{\mathrm{f}} G\right)_{\text {products }}-\sum\left(v \Delta_{\mathrm{f}} G\right) \text { reactants }
$$

\section{Results and discussion}

\subsection{Thermodynamic analysis of the reaction network and feasibility of main reactions}

Scheme 1 illustrates the main possible reaction pathways in the 1-butene metathesis reaction network. Ethene, hexene, propene, and pentene are the main metathesis products. To improve the selectivity for Metathesis I, 1-butene isomerization and the subsequent Metathesis II should be suppressed. We first analyzed the reaction network from the viewpoint of thermodynamics. $\Delta_{\mathrm{r}} G$ values can be used to infer whether the reaction was thermodynamically favored at a given temperature. It is generally accepted that a reaction occurs spontaneously when $\Delta_{\mathrm{r}} G<0$. Reactions are possibly favorable when $0<$ $\Delta_{\mathrm{r}} G<50 \mathrm{~kJ} / \mathrm{mol}$ [23]. As shown in Fig. 1, the $\Delta_{\mathrm{r}} G$ values for Metathesis I and IV were around 4-6 kJ/mol and increased with the reaction temperature, indicating that low temperature was favorable for the target Metathesis I reaction. $\Delta_{\mathrm{r}} G$ for Metathesis II was below 0 and was as low as $-6 \mathrm{~kJ} / \mathrm{mol}$ for 1 -butene isomerization. This means the double bond isomerization and side Metathesis II reaction occurs more easily than the Metath-

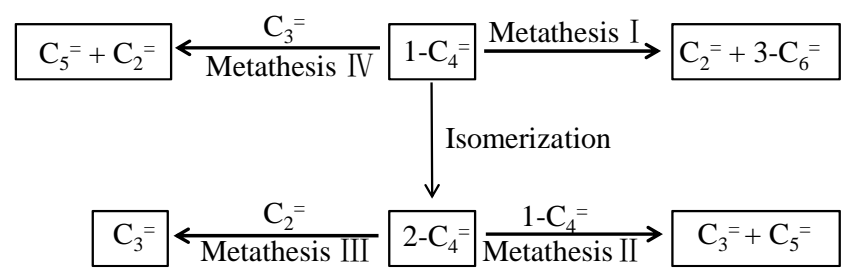

Scheme 1. Possible reaction pathways of 1-butene self-metathesis over Mo-based heterogeneous catalysts.

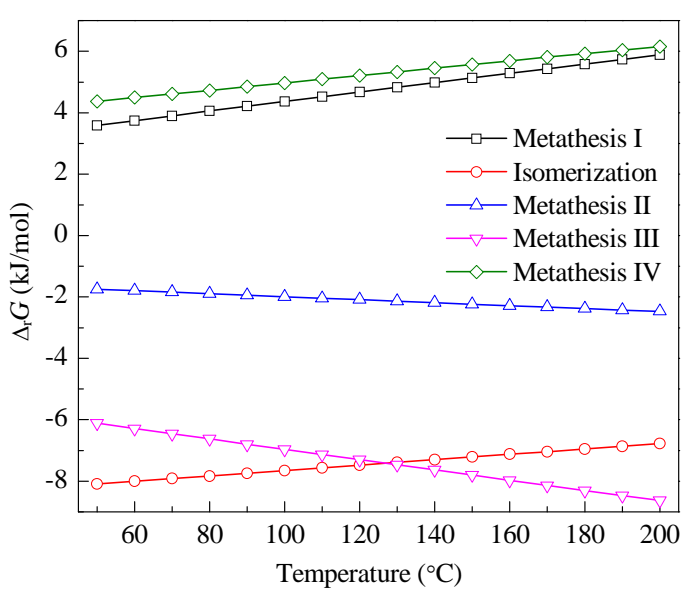

Fig. 1. Gibbs free energy change in the reaction network at different temperatures.

esis I reaction. Thus, the metathesis catalyst should be carefully optimized to selectively promote the Metathesis I reaction.

\subsection{Catalytic performance of Mo-based catalysts on different supports}

Mo/HMOR- $\mathrm{Al}_{2} \mathrm{O}_{3}$ [24], $\mathrm{Mo} / \mathrm{Al}_{2} \mathrm{O}_{3}$ [25], and $\mathrm{Mo} / \mathrm{SiO}_{2}$ [7] have been proved good metathesis catalyst candidates in different metathesis catalytic reactions. Here, they were evaluated in the 1-butene self-metathesis reaction. The detailed catalytic results under different reaction conditions are summarized in Table 1. Dramatic differences between feed conversion and product selectivity were observed for the different supported catalyst systems. Over the $6 \mathrm{Mo} / \mathrm{HMOR}-50 \mathrm{Al}_{2} \mathrm{O}_{3}$ catalyst, high 1-butene conversion was observed. However, propene selectivity was much higher than that of ethene, indicating that Metathesis II dominated in reaction network; i.e., 1-butene first isomerized to 2-butene, followed by the cross-metathesis of 1-butene and 2-butene. This behavior was in agreement with our previous report in which $\mathrm{Mo} / \mathrm{HMOR}-\mathrm{Al}_{2} \mathrm{O}_{3}$ was the effective metathesis catalyst for the conversion of 1-butene to propene [24]. Product selectivity for 2-butene was also high, which meant $6 \mathrm{Mo} / \mathrm{HMOR}-50 \mathrm{Al}_{2} \mathrm{O}_{3}$ was an effective double-bond isomerization catalyst. To suppress the formation of 2-butene, the $6 \mathrm{Mo} / \mathrm{NaMOR}-50 \mathrm{Al}_{2} \mathrm{O}_{3}$ catalysts was used. As listed in Table 1, product selectivity for ethene and hexene improved, whereas 1-butene conversion decreased markedly compared with the case for Mo/HMOR- $\mathrm{Al}_{2} \mathrm{O}_{3}$. Low support acidity suppressed both the isomerization and metathesis activity of the system.

When $6 \mathrm{Mo} / \mathrm{Al}_{2} \mathrm{O}_{3}-\mathrm{A}$ was used, high ethene selectivity was observed on the premise of high 1-butene conversion. The molar selectivity for ethene and hexene exceeded $85 \%$, which indicated that the self-metathesis of 1-butene predominated in the metathesis reaction network. In contrast, $6 \mathrm{Mo} / \mathrm{SiO}_{2}$ showed poor catalytic performance at $100{ }^{\circ} \mathrm{C}$ and 1-butene conversion increased with the reaction temperature. However, ethene selectivity decreased sharply. The selectivity for 2-butene exceeded $90 \%$. In other words, $6 \mathrm{Mo} / \mathrm{SiO}_{2}$ was a good double-bond isomerization catalyst, especially at high reaction 
Table 1

Catalytic performance of Mo-based heterogeneous catalysts in the self-metathesis reaction of 1-butene.

\begin{tabular}{|c|c|c|c|c|c|c|c|c|}
\hline \multirow{2}{*}{ Catalyst } & \multirow{2}{*}{ Temperature $\left({ }^{\circ} \mathrm{C}\right)$} & \multirow{2}{*}{ Conversion (\%) } & \multicolumn{5}{|c|}{ Product selectivity (mol\%) } & \multirow[b]{2}{*}{ Others } \\
\hline & & & $\mathrm{C}_{2}=$ & $\mathrm{C}_{3}=$ & $\mathrm{C}_{5}=$ & $\mathrm{C}_{6}=$ & $2-\mathrm{C}_{4}=$ & \\
\hline $6 \mathrm{Mo} / \mathrm{HMOR}-50 \mathrm{Al}_{2} \mathrm{O}_{3}$ & 100 & 76.8 & 11.3 & 29.9 & 24.3 & 16.3 & 14.0 & 4.2 \\
\hline $6 \mathrm{Mo} / \mathrm{NaMOR}-50 \mathrm{Al}_{2} \mathrm{O}_{3}$ & 100 & 25.9 & 36.5 & 1.4 & 1.6 & 58.6 & 1.6 & 0.3 \\
\hline \multirow[t]{2}{*}{$6 \mathrm{Mo} / \mathrm{Al}_{2} \mathrm{O}_{3}-\mathrm{A}$} & 100 & 45.3 & 40.6 & 11.9 & 9.1 & 36.2 & 0.7 & 1.5 \\
\hline & 120 & 48.5 & 33.2 & 16.3 & 13.4 & 32.6 & 2.1 & 2.4 \\
\hline \multirow[t]{3}{*}{$6 \mathrm{Mo} / \mathrm{SiO}_{2}$} & 100 & 8.2 & 32.8 & 4.1 & 5.1 & 40.8 & 16.6 & 0.6 \\
\hline & 150 & 19.4 & 1.7 & 1.9 & 1.9 & 1.9 & 91.6 & 1.0 \\
\hline & 200 & 41.9 & 0.9 & 1.6 & 1.5 & 1.0 & 94.4 & 0.6 \\
\hline
\end{tabular}

Reaction conditions: $1.0 \mathrm{MPa}$, weight hourly space velocity (WHSV) $=3 \mathrm{~h}^{-1}, \mathrm{TOS}=15 \mathrm{~h}$.

temperature.

In general, $6 \mathrm{Mo} / \mathrm{Al}_{2} \mathrm{O}_{3}-\mathrm{A}$ was a good candidate for the 1-butene self-metathesis reaction among the above evaluated catalysts. This catalyst could effectively promote the target reaction at low reaction temperature. Over $6 \mathrm{Mo} / \mathrm{Al}_{2} \mathrm{O}_{3}-\mathrm{A}$, metathesis of 1-butene and 2-butene to propene/pentene was the main side metathesis reaction. The double-bond isomerization reaction of butene, the key intermediate step determining the target olefin selectivity, was sensitive to catalyst acidity and reaction temperature. Low acidity and temperature could suppress 2-butene formation and the following Metathesis II side reaction. Thus, $\mathrm{Mo} / \mathrm{Al}_{2} \mathrm{O}_{3}$ with proper acidity was proved to be a good candidate catalyst for 1-butene self-metathesis.

\subsection{Structural properties and catalytic performance of $\mathrm{xMo} / \mathrm{Al}_{2} \mathrm{O}_{3}$-A catalysts with different Mo loadings}

It is generally accepted that metathesis activity is closely related to the metal loading. Optimal Mo loading on the $\mathrm{Al}_{2} \mathrm{O}_{3}-\mathrm{A}$ support was therefore investigated. Table 2 lists the physicochemical properties of $x \mathrm{Mo} / \mathrm{Al}_{2} \mathrm{O}_{3}$-A samples. The results of $\mathrm{N}_{2}$ physisorption experiments revealed that the BET surface area of the $\mathrm{Al}_{2} \mathrm{O}_{3}$-A support was $326 \mathrm{~m}^{2} / \mathrm{g}$ and decreased upon Mo loading [26]. Quantitative analysis of $\mathrm{NH}_{3}$-TPD profiles showed that the acid density of $\mathrm{Al}_{2} \mathrm{O}_{3}-\mathrm{A}$ decreased from 0.335 to 0.295 $\mathrm{mmol} / \mathrm{g}$ after $2 \%$ Mo loading. However, the total number of acid sites increased with the Mo content when the Mo loading was higher than $4 \%$. For $10 \mathrm{Mo} / \mathrm{Al}_{2} \mathrm{O}_{3}-\mathrm{A}$, the total acid density was higher than that of the $\mathrm{Al}_{2} \mathrm{O}_{3}-\mathrm{A}$ support. As shown in Fig. 2, the desorption peak intensity at around $240{ }^{\circ} \mathrm{C}$ was the biggest

Table 2

Textural and reducibility properties of $x \mathrm{Mo} / \mathrm{Al}_{2} \mathrm{O}_{3}-\mathrm{A}$ catalysts.

\begin{tabular}{lcccc}
\hline Catalyst & $\begin{array}{c}A_{\mathrm{BET}}{ }^{\mathrm{a}} \\
\left(\mathrm{m}^{2} / \mathrm{g}\right)\end{array}$ & $\begin{array}{c}\text { Pore volume } \\
\left(\mathrm{cm}^{3} / \mathrm{g}\right)\end{array}$ & $\begin{array}{c}\text { Acidity } \\
(\mathrm{mmol} / \mathrm{g})\end{array}$ & $\begin{array}{c}I_{475^{\circ} \mathrm{C}} / I_{\text {total }}{ }^{\mathrm{c}} \\
(\%)\end{array}$ \\
\hline $\mathrm{Al}_{2} \mathrm{O}_{3}-\mathrm{A}$ & 326 & 0.75 & 0.334 & - \\
$2 \mathrm{Mo} / \mathrm{Al}_{2} \mathrm{O}_{3}-\mathrm{A}$ & 280 & 0.66 & 0.295 & 4 \\
$4 \mathrm{Mo} / \mathrm{Al}_{2} \mathrm{O}_{3}-\mathrm{A}$ & 268 & 0.63 & 0.301 & 6 \\
$6 \mathrm{Mo} / \mathrm{Al}_{2} \mathrm{O}_{3}-\mathrm{A}$ & 267 & 0.61 & 0.302 & 11 \\
$8 \mathrm{Mo} / \mathrm{Al}_{2} \mathrm{O}_{3}-\mathrm{A}$ & 266 & 0.60 & 0.319 & 14 \\
$10 \mathrm{Mo} / \mathrm{Al}_{2} \mathrm{O}_{3}-\mathrm{A}$ & 256 & 0.58 & 0.344 & 16 \\
\hline
\end{tabular}

a Determined by $\mathrm{N}_{2}$ adsorption isotherms.

b Determined by quantitative analysis of $\mathrm{NH}_{3}$-TPD profiles.

c Intensity ratio of the peak at around $475^{\circ} \mathrm{C}$ determined by the quantitative analysis of $\mathrm{H}_{2}$-TPR profiles. among all the samples, indicating that Mo loading induced the formation of new weak acid sites. Mo species preferentially interacted with the strong acid sites on the $\mathrm{Al}_{2} \mathrm{O}_{3}$ support and a high Mo content led to the formation of new acid sites. Similar phenomena were also observed by Miranda et al. [27]. Crystalline $\mathrm{MoO}_{3}$ was not observed in the XRD patterns of the $x \mathrm{Mo} / \mathrm{Al}_{2} \mathrm{O}_{3}$-A catalysts (Fig. 3).

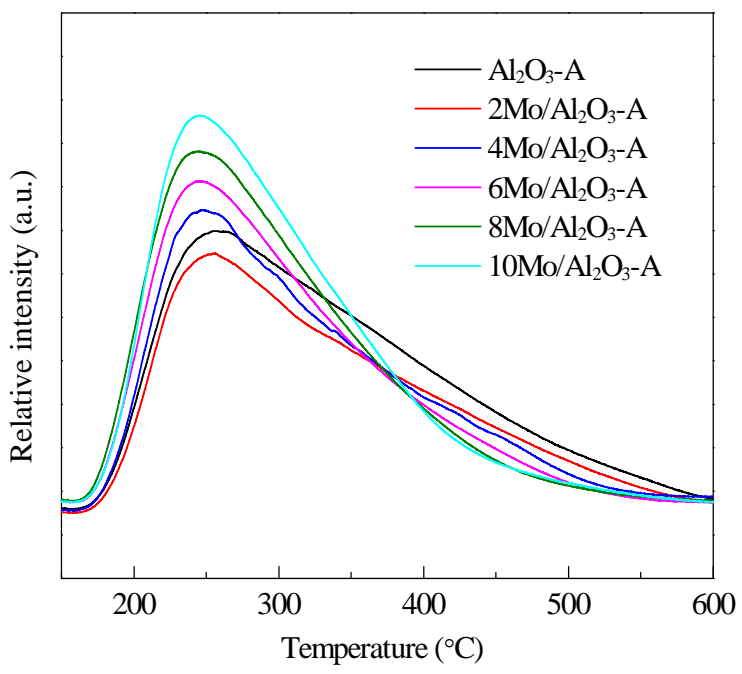

Fig. 2. $\mathrm{NH}_{3}-\mathrm{TPD}$ profiles of $x \mathrm{Mo} / \mathrm{Al}_{2} \mathrm{O}_{3}-\mathrm{A}$ samples.

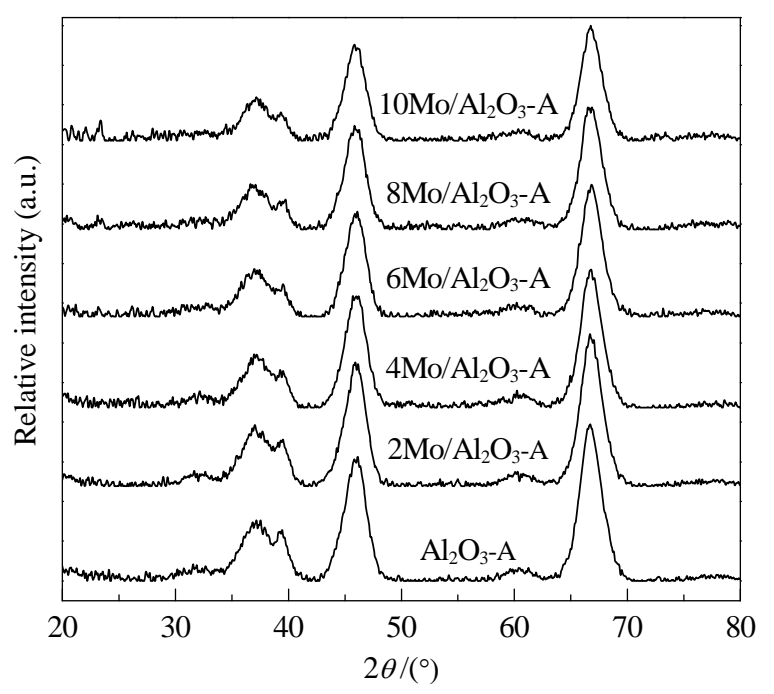

Fig. 3. XRD profiles of $x \mathrm{Mo} / \mathrm{Al}_{2} \mathrm{O}_{3}-\mathrm{A}$ samples. 


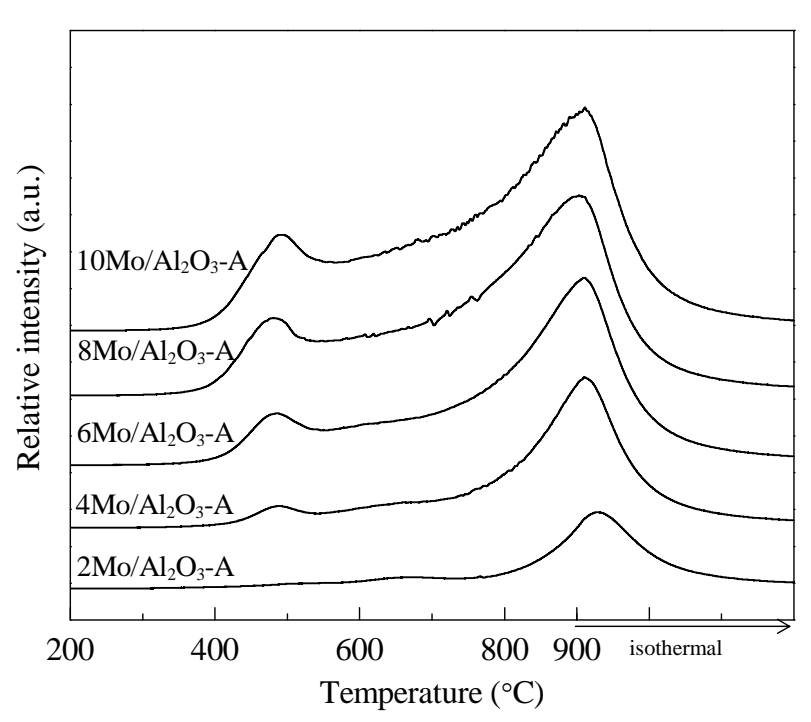

Fig. 4. $\mathrm{H}_{2}$-TPR profiles of $x \mathrm{Mo} / \mathrm{Al}_{2} \mathrm{O}_{3}-\mathrm{A}$ catalysts.

It is well accepted that the olefin metathesis reaction follows the metal carbene mechanism over heterogeneous catalysts. The redox properties of the supported metal oxides are directly associated with carbene formation. Interactions between Mo species and alumina were investigated by $\mathrm{H}_{2}$-TPR measurements, as shown in Fig. 4. The $\mathrm{H}_{2}$-TPR profiles of all the samples contained two main reduction peaks. The peak at low temperature was consistent with the reduction of octahedral Mo species to tetrahedral Mo species dispersed on the $\mathrm{Al}_{2} \mathrm{O}_{3}$-A support [28]. The peak signal at high temperature was attributed to both the further reduction of the excess octahedral Mo species and the partial reduction of tetrahedral Mo species strongly interacting with $\mathrm{Al}_{2} \mathrm{O}_{3}$ [29]. As illustrated in Fig. 4, the ratio of the reduction peak area at $475{ }^{\circ} \mathrm{C}$ rose with Mo loading, indicating that the quantity of octahedral Mo species increased with Mo loading. Quantitative analysis results after fitting are listed in Table 2. Meanwhile, the reduction peak at higher temperature shifted to lower temperature with increasing Mo loading, indicating that the interaction between Mo species and the support weakened and aggregated species formed.

The effects of Mo content of the $x \mathrm{Mo} / \mathrm{Al}_{2} \mathrm{O}_{3}-\mathrm{A}$ catalysts on the self-metathesis of 1-butene were investigated. As displayed in Fig. 5(a), the highest butene conversion was observed over the $10 \mathrm{Mo} / \mathrm{Al}_{2} \mathrm{O}_{3}-\mathrm{A}$ catalyst. Similar activity was observed when the Mo loading was in the range of $6 \%-8 \%$. When the Mo content was $2 \%$, butene conversion was low (15\%). It should be noted that all the catalysts showed good catalytic stability during the evaluation period.

In the case of product selectivity, the situation was quite complicated. Propene/pentene selectivity increased with Mo loading and followed the trend of butene conversion. Combined with the $\mathrm{NH}_{3}$-TPD results, it was deduced that high acid density promoted the double-bond isomerization and following Metathesis II reaction. According to the thermodynamic results, $\Delta_{\mathrm{r}} G$ of Metathesis II was much lower than that of Metathesis I. Once 2-butene was produced, Metathesis II occurred preferentially, which led to the formation of propene and pentene. When the Mo loading was in the range of $2 \%-6 \%$, product selectivity for ethene was around $40 \%$. Compared with ethene, selectivity for hexene was a little lower because of the oli-
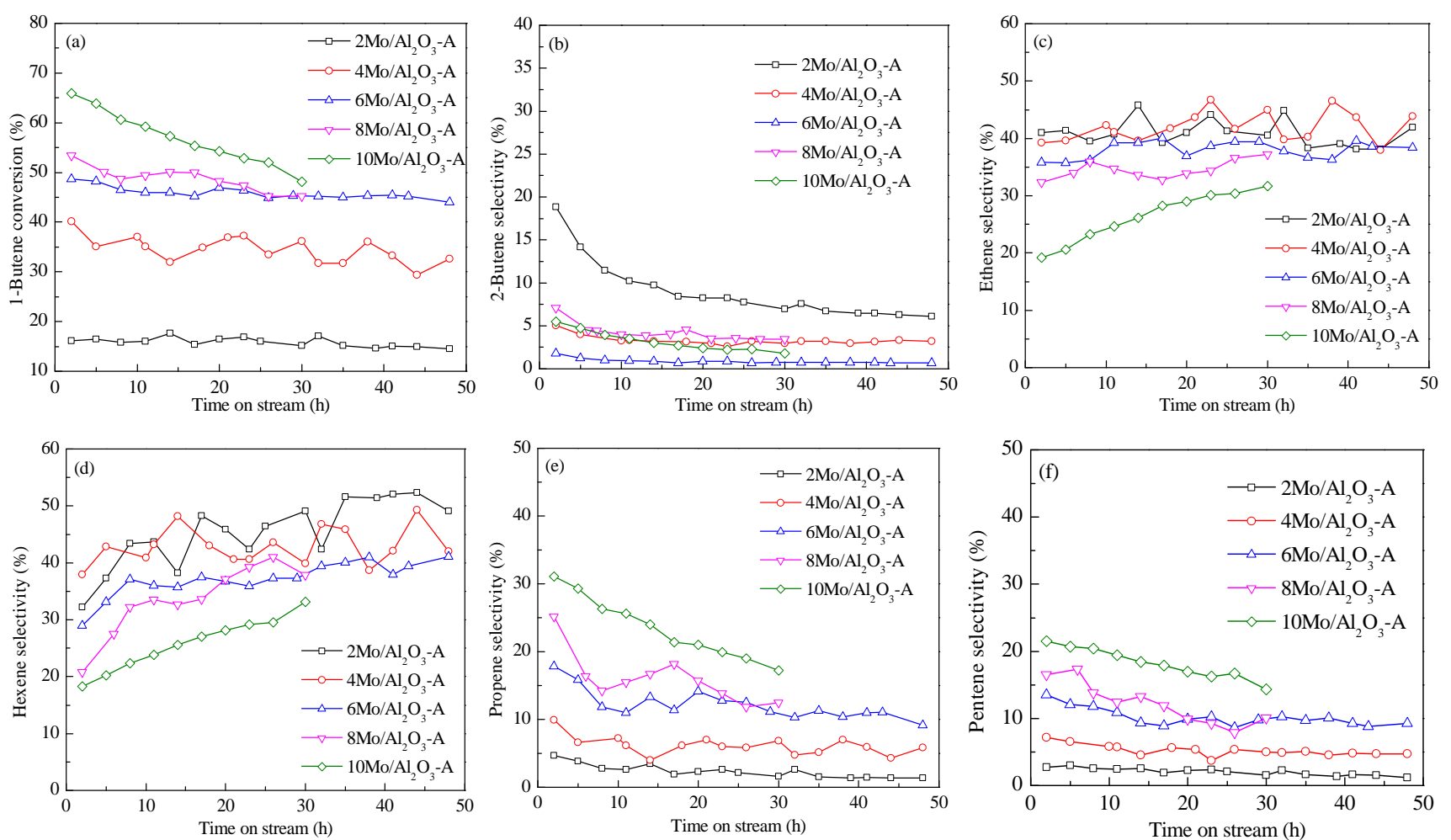

Fig. 5. Catalytic performance of $x \mathrm{Mo} / \mathrm{Al}_{2} \mathrm{O}_{3}-\mathrm{A}$ in the 1-butene self-metathesis reaction. (a) 1-Butene conversion; (b) 2-Butene selectivity; (c) Ethene selectivity; (d) Hexene selectivity; (e) Propene selectivity; (f) Pentene selectivity. Reaction conditions: $100{ }^{\circ} \mathrm{C}, 1.0 \mathrm{MPa}, \mathrm{WHSV}=3 \mathrm{~h}{ }^{-1}$. 
gomerization side reaction. Taking into account both conversion and selectivity, the optimal Mo loading of $x \mathrm{Mo} / \mathrm{Al}_{2} \mathrm{O}_{3}-\mathrm{A}$ was around $6 \%$.

\subsection{Optimization of the reaction conditions}

The metathesis catalytic activity of $6 \mathrm{Mo} / \mathrm{Al}_{2} \mathrm{O}_{3}-\mathrm{A}$ was closely linked with the reaction parameters. The effects of reaction temperature, pressure, and feed space velocity on product distribution were investigated in detail. It is generally accepted that Mo-based heterogeneous metathesis catalysts are activated at medium to high temperature $\left(150-300{ }^{\circ} \mathrm{C}\right.$ ) [30]. For the 1-butene self-metathesis reaction, the situation was quite different. As shown in Fig. 6, 1-butene conversion increased with the reaction temperature. It should be pointed out that propene/pentene selectivity also increased with the reaction temperature although ethene/hexene were the main products. At $60{ }^{\circ} \mathrm{C}$, the selectivity for ethene and hexene was high (90\%). However, 1-butene conversion was low (20\%). The optimal reaction temperature was between 80 and $100^{\circ} \mathrm{C}$.

Although 1-butene self-metathesis is an equal molecular reaction, reaction pressure also influenced the catalyst activity because high pressure could increase the collision probability of reactant molecules. As illustrated in Fig. 7, 1-butene conversion increased from $37 \%$ to $47 \%$ with rising reaction pressure. High reaction pressure also promoted the Metathesis II side reaction. Propene selectivity slightly increased with pressure. Suitable reaction pressure should be chosen to guarantee the

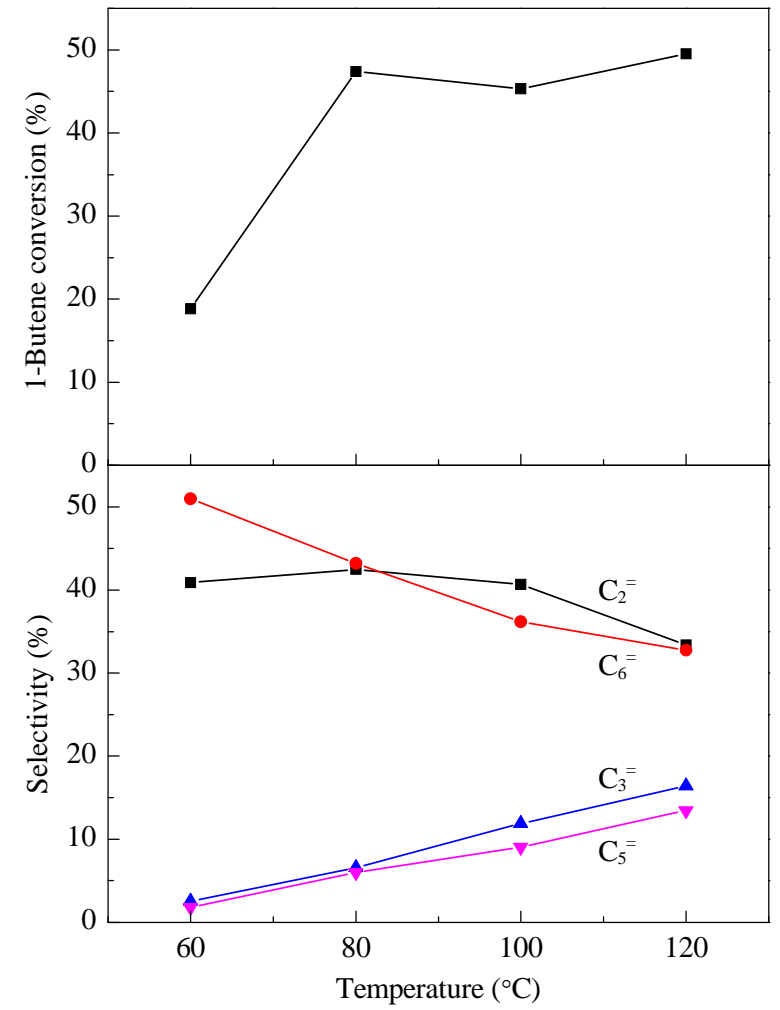

Fig. 6. Influence of reaction temperature on the catalytic performance of $6 \mathrm{Mo} / \mathrm{Al}_{2} \mathrm{O}_{3}-\mathrm{A}$. Reaction conditions: $1.0 \mathrm{MPa}$, WHSV $=3 \mathrm{~h}^{-1}$, TOS $=15$ h.

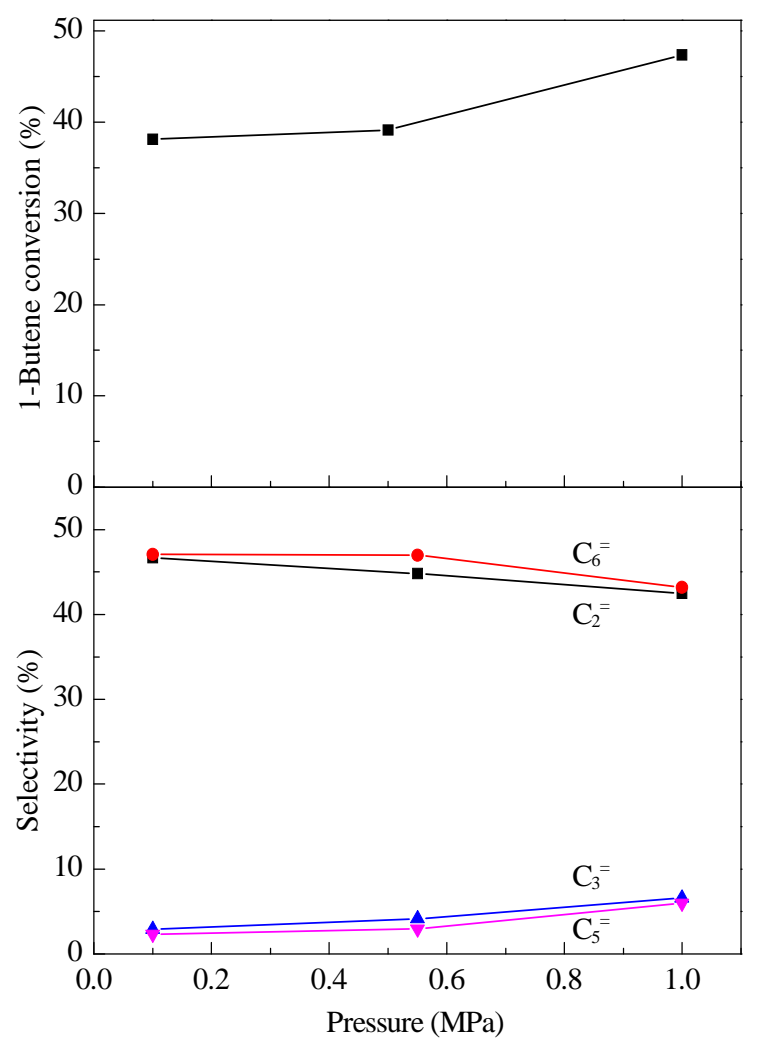

Fig. 7. Influence of reaction pressure on the catalytic performance of $6 \mathrm{Mo} / \mathrm{Al}_{2} \mathrm{O}_{3}-\mathrm{A}$. Reaction conditions: $80^{\circ} \mathrm{C}, \mathrm{WHSV}=3 \mathrm{~h}^{-1}$, TOS $=15 \mathrm{~h}$.

high yields of ethene and hexene. Fig. 8 presents the influence of 1-butene WHSV on the metathesis activity of $6 \mathrm{Mo} / \mathrm{Al}_{2} \mathrm{O}_{3}$ - $\mathrm{A}$. It was obvious that 1-butene conversion decreased with rising WHSV. However, the selectivity for Metathesis I increased with WHSV. Thus, a long residence time on the catalyst could promote double-bond isomerization and the subsequent Metathesis II reaction. In contrast, high WHSV of 1-butene was beneficial for Metathesis I (ethene/hexene).

To achieve high yields of ethene and hexene, both 1-butene conversion and product selectivity should be considered. On the basis of the above discussion, the relative optimal reaction conditions for the $6 \mathrm{Mo} / \mathrm{Al}_{2} \mathrm{O}_{3}-\mathrm{A}$ catalyst in the 1-butene self-metathesis reaction are $80-100{ }^{\circ} \mathrm{C}, 0.5-1.0 \mathrm{MPa}$ and 3-4.5 $\mathrm{h}^{-1}$. Under the optimal conditions, 1-butene conversion could be as high as $47 \%$ on the premise of $85 \%$ product selectivity for ethene and hexene.

\subsection{Effect of $\mathrm{Al}_{2} \mathrm{O}_{3}$ support properties on the catalytic performance of $6 \mathrm{Mo} / \mathrm{Al}_{2} \mathrm{O}_{3}-\mathrm{X}$}

It is well known that the metathesis performance of Mo-based catalysts is influenced by the nature of the support $[31,32]$. On the basis of the above results, $\mathrm{Al}_{2} \mathrm{O}_{3}$ was chosen as the support. The textural and acid properties of $\mathrm{Al}_{2} \mathrm{O}_{3}$ may influence the state of Mo species and consequently metathesis activity. To investigate the relationship between reaction performance and support nature, a series of $\mathrm{Al}_{2} \mathrm{O}_{3}$ supports with different textural properties were selected. To distinguish the 


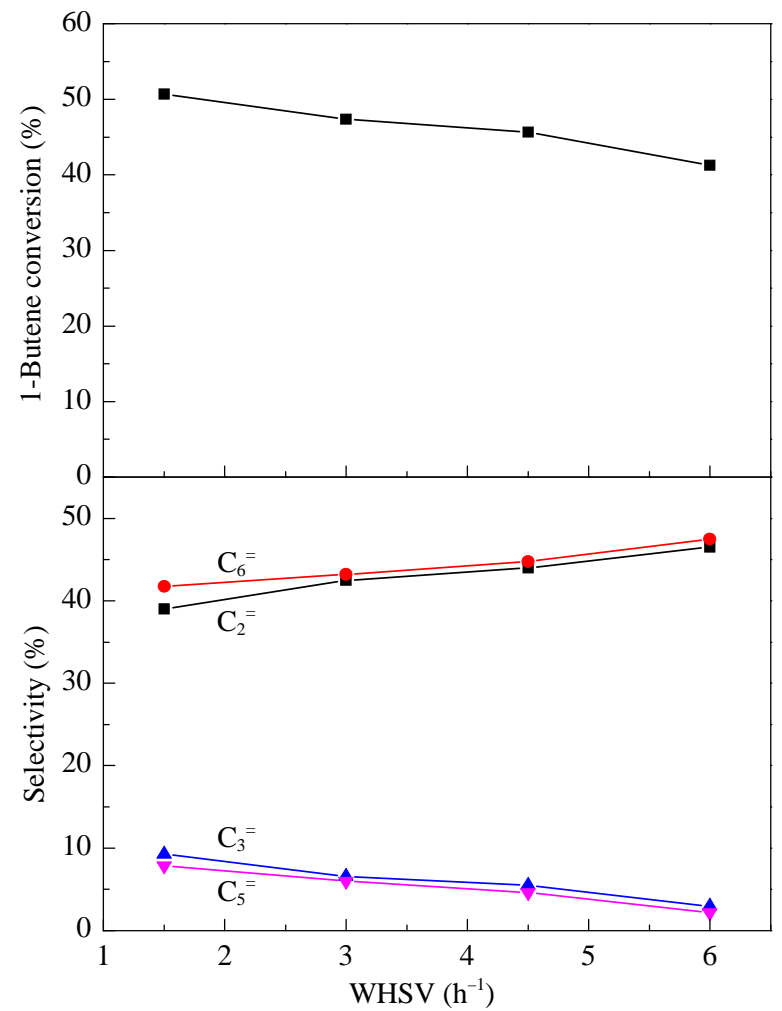

Fig. 8. Influence of WHSV on the catalytic performance of $6 \mathrm{Mo} / \mathrm{Al}_{2} \mathrm{O}_{3}-\mathrm{A}$. Reaction conditions: $80^{\circ} \mathrm{C}, 1.0 \mathrm{MPa}$, TOS $=15 \mathrm{~h}$.

different alumina supports, $\mathrm{Al}_{2} \mathrm{O}_{3}$ from the above discussion is designated as $\mathrm{Al}_{2} \mathrm{O}_{3}-\mathrm{A}$; the other three supports are labeled as $\mathrm{Al}_{2} \mathrm{O}_{3}-\mathrm{B},-\mathrm{C}$, and $-\mathrm{D}$.

Textural and physicochemical properties of the $\mathrm{Al}_{2} \mathrm{O}_{3}-X$ supports and $6 \mathrm{Mo} / \mathrm{Al}_{2} \mathrm{O}_{3}-x$ catalysts are listed in Table 3 . The BET surface areas of the supports ranged from 137 to 326 $\mathrm{m}^{2} / \mathrm{g}$. Introduction of Mo species simultaneously decreased the surface area and pore volume. The XRF results indicated the Mo loading on each support was around 5\%.

Quantitative analysis of the $\mathrm{NH}_{3}$-TPD profiles indicated that the acid density of $\mathrm{Al}_{2} \mathrm{O}_{3}-X$ followed a similar trend to that of BET surface area. Py-IR spectra were acquired to obtain more information about the types of acid sites. As shown in Fig. 9, $\mathrm{Al}_{2} \mathrm{O}_{3}-\mathrm{A}$ only contained Lewis acid sites $\left(1450 \mathrm{~cm}^{-1}\right)$. Mo spe-

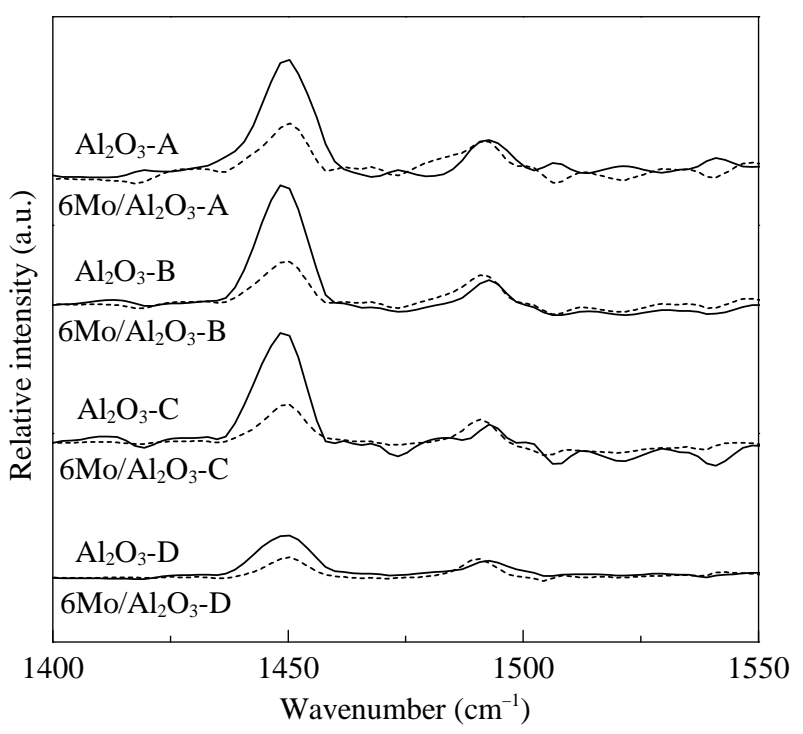

Fig. 9. Py-IR spectra of $6 \mathrm{Mo} / \mathrm{Al}_{2} \mathrm{O}_{3}-x$ catalysts.

cies interacted with the Lewis acid sites, which weakened the intensity of the peak at $1450 \mathrm{~cm}^{-1}$. As mentioned in Section 3.3, Mo loading may introduce new acid sites on $\mathrm{Mo} / \mathrm{Al}_{2} \mathrm{O}_{3}$ catalysts. The Py-IR results indicated that no new Brönsted acid sites were formed by Mo loading. The number of Lewis acid sites on $\mathrm{Al}_{2} \mathrm{O}_{3}$-D was the lowest among the four supports.

UV-Vis diffuse reflectance spectra can reveal the surrounding geometries of Mo species. Fig. 10 shows the UV-Vis spectra of $6 \mathrm{Mo} / \mathrm{Al}_{2} \mathrm{O}_{3}-X$ catalysts. Two bands centered at around 220 and $270 \mathrm{~nm}$ were observed. The band at $220-250 \mathrm{~nm}$ is commonly attributed to tetrahedral molybdate, while that at $260-320 \mathrm{~nm}$ is assigned to the Mo-O-Mo bridge of octahedral molybdate and polymerized molybdate species [28,33]. The content of octahedral molybdate in $6 \mathrm{Mo} / \mathrm{Al}_{2} \mathrm{O}_{3}$-D was the highest among that of the four samples because of its lowest surface area. This was in accordance with the quantitative analysis results of $\mathrm{H}_{2}$-TPR (Table 3).

The dispersion of Mo species on alumina was further characterized using HRTEM images. As illustrated in Fig. 11(a), a uniform distribution of Mo nanoparticles over the alumina support was observed. Little difference was observed between the $6 \mathrm{Mo} / \mathrm{Al}_{2} \mathrm{O}_{3}-\mathrm{B}$ and $-\mathrm{C}$ samples. In the case of $6 \mathrm{Mo} / \mathrm{Al}_{2} \mathrm{O}_{3}-\mathrm{D}$,

Table 3

Physicochemical properties of the $\mathrm{Al}_{2} \mathrm{O}_{3}-x$ supports and $6 \mathrm{Mo} / \mathrm{Al}_{2} \mathrm{O}_{3}-x$ catalysts.

\begin{tabular}{|c|c|c|c|c|c|c|}
\hline Sample & Mo loading a (\%) & $A_{\mathrm{BET}} \mathrm{b}^{\mathrm{b}}\left(\mathrm{m}^{2} / \mathrm{g}\right)$ & Pore volume ${ }^{\mathrm{b}}\left(\mathrm{cm}^{3} / \mathrm{g}\right)$ & Pore diameter $\mathrm{b}(\mathrm{nm})$ & Acidity ${ }^{\mathrm{c}}(\mathrm{mmol} / \mathrm{g})$ & $I_{475^{\circ} \mathrm{C}} / I_{\text {total }} \mathrm{d}(\%)$ \\
\hline $\mathrm{Al}_{2} \mathrm{O}_{3}-\mathrm{A}$ & - & 326 & 0.75 & 6.5 & 0.335 & - \\
\hline $\mathrm{Al}_{2} \mathrm{O}_{3}-\mathrm{B}$ & - & 289 & 0.76 & 7.7 & 0.293 & - \\
\hline $\mathrm{Al}_{2} \mathrm{O}_{3}-\mathrm{C}$ & - & 213 & 0.75 & 10.3 & 0.239 & - \\
\hline $\mathrm{Al}_{2} \mathrm{O}_{3}-\mathrm{D}$ & - & 137 & 0.65 & 13.6 & 0.149 & - \\
\hline $6 \mathrm{Mo} / \mathrm{Al}_{2} \mathrm{O}_{3}-\mathrm{A}$ & 5.34 & 267 & 0.61 & 7.1 & 0.302 & 11 \\
\hline $6 \mathrm{Mo} / \mathrm{Al}_{2} \mathrm{O}_{3}-\mathrm{B}$ & 5.66 & 254 & 0.65 & 8.3 & 0.271 & 11 \\
\hline $6 \mathrm{Mo} / \mathrm{Al}_{2} \mathrm{O}_{3}-\mathrm{C}$ & 5.13 & 207 & 0.65 & 10.7 & 0.238 & 13 \\
\hline $6 \mathrm{Mo} / \mathrm{Al}_{2} \mathrm{O}_{3}-\mathrm{D}$ & 5.13 & 135 & 0.57 & 14.4 & 0.143 & 17 \\
\hline
\end{tabular}

a Determined by XRF.

b Determined by $\mathrm{N}_{2}$ adsorption isotherms.

c Determined by quantitative analysis of $\mathrm{NH}_{3}$-TPD profiles.

${ }^{\mathrm{d}}$ Intensity ratio of the peak at around $475^{\circ} \mathrm{C}$ determined by the quantitative analysis of $\mathrm{H}_{2}$-TPR profiles. 


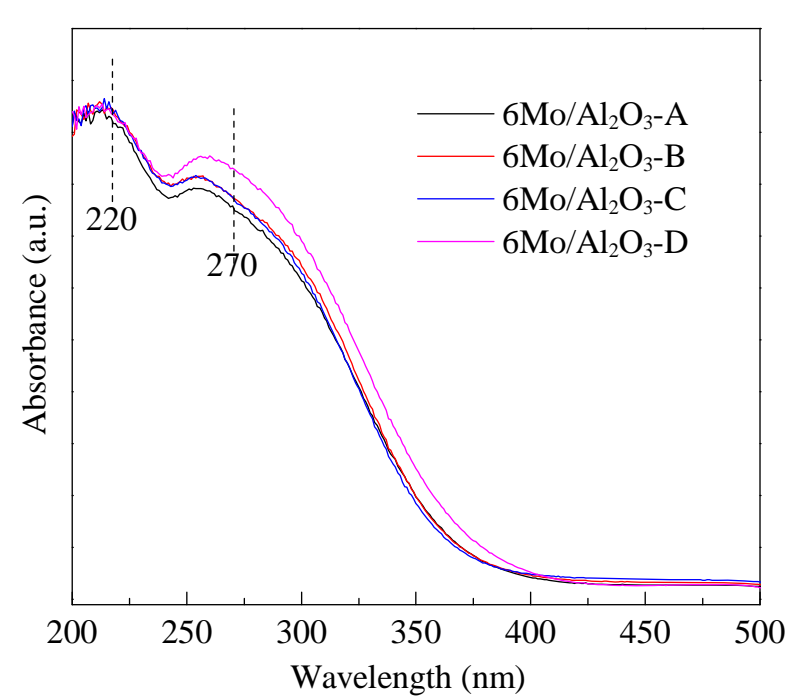

Fig. 10. UV-Vis spectra of $6 \mathrm{Mo} / \mathrm{Al}_{2} \mathrm{O}_{3}-X$ catalysts.

the dispersion of Mo species was poor and some particles aggregated together into clusters, as indicated in Fig. 11(d). These observations are in accordance with the UV-Vis and $\mathrm{H}_{2}$-TPR results. In general, a high BET surface area of the alumina support is beneficial for the dispersion of Mo species.

Metathesis activities of the $6 \mathrm{Mo} / \mathrm{Al}_{2} \mathrm{O}_{3}-x$ catalysts were investigated and are listed in Table 4 . The highest 1-butene conversion was observed on $6 \mathrm{Mo} / \mathrm{Al}_{2} \mathrm{O}_{3}-\mathrm{A}$ and it gradually decreased following the order of $6 \mathrm{Mo} / \mathrm{Al}_{2} \mathrm{O}_{3}-\mathrm{B}, 6 \mathrm{Mo} / \mathrm{Al}_{2} \mathrm{O}_{3}-\mathrm{C}$, and $6 \mathrm{Mo} / \mathrm{Al}_{2} \mathrm{O}_{3}-\mathrm{D}$. Combined with the above characterization results, it was deduced that effective dispersion of Mo species and high acid density were beneficial for the conversion of butene. Although the highest 1-butene conversion was obtained on $6 \mathrm{Mo} / \mathrm{Al}_{2} \mathrm{O}_{3}-\mathrm{A}$, its ethene/hexene selectivity was lower than those of $6 \mathrm{Mo} / \mathrm{Al}_{2} \mathrm{O}_{3}-\mathrm{B}$ and $6 \mathrm{Mo} / \mathrm{Al}_{2} \mathrm{O}_{3}-\mathrm{C}$. Thus, a large number of acid sites may promote the double-bond isomerization and
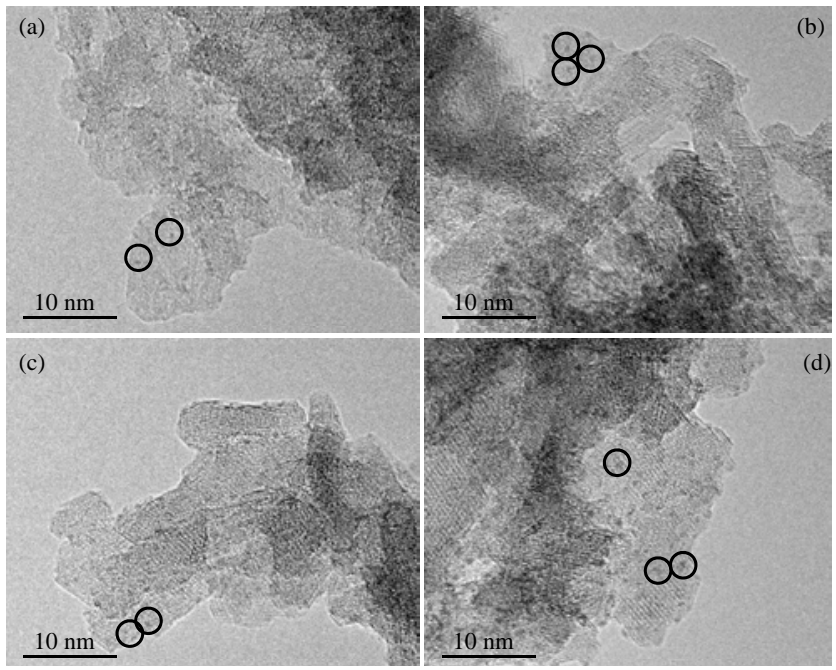

Fig. 11. HRTEM images of $6 \mathrm{Mo} / \mathrm{Al}_{2} \mathrm{O}_{3}-x$ catalysts where $x$ is (a) $\mathrm{A}$, (b) $\mathrm{B}$, (c) C, and (d) D.

subsequent metathesis II reaction. To suppress the side metathesis reaction, suitable acid density was necessary. In the case of $6 \mathrm{Mo} / \mathrm{Al}_{2} \mathrm{O}_{3}-\mathrm{D}$, poor catalytic stability was observed. The high ratio of octahedral Mo species led to the rapid deactivation of the catalyst.

In general, the 1-butene double-bond isomerization reaction was an important step that determined the product selectivity. Suppression of isomerization was critical to guarantee the selectivity for metathesis I. For the $\mathrm{Mo} / \mathrm{Al}_{2} \mathrm{O}_{3}$ catalyst, low reaction temperature and high WHSV were beneficial to increase the ethene/hexene selectivity. The optimal Mo loading was between $4 \%$ and $6 \% . \mathrm{Al}_{2} \mathrm{O}_{3}$ with a large surface area contributed to the effective dispersion of Mo species on the support. To guarantee the good catalytic performance of $\mathrm{Mo} / \mathrm{Al}_{2} \mathrm{O}_{3}$ catalysts, the acid density and state of Mo species should be balanced.

Table 4

Catalytic performance of $6 \mathrm{Mo} / \mathrm{Al}_{2} \mathrm{O}_{3}-x$ in the self-metathesis reaction of 1-butene.

\begin{tabular}{|c|c|c|c|c|c|c|c|c|}
\hline \multirow{2}{*}{ Catalyst } & \multirow{2}{*}{ Time (h) } & \multirow{2}{*}{ Conversion (\%) } & \multicolumn{5}{|c|}{ Product selectivity (\%) } & \multirow[b]{2}{*}{ Others } \\
\hline & & & $\mathrm{C}_{2}=$ & $\mathrm{C}_{3}=$ & $\mathrm{C}_{5}=$ & $\mathrm{C}_{6}=$ & $2-\mathrm{C}_{4}=$ & \\
\hline \multirow[t]{4}{*}{$6 \mathrm{Mo} / \mathrm{Al}_{2} \mathrm{O}_{3}-\mathrm{A}$} & 5 & 48.2 & 35.7 & 15.9 & 12.1 & 33.2 & 1.2 & 1.9 \\
\hline & 15 & 46.2 & 38.4 & 11.8 & 10.9 & 36.1 & 0.9 & 1.9 \\
\hline & 25 & 46.2 & 38.3 & 12.1 & 10.5 & 36.8 & 0.9 & 1.4 \\
\hline & 35 & 45.0 & 36.6 & 11.3 & 9.7 & 40.1 & 0.8 & 1.5 \\
\hline \multirow[t]{4}{*}{$6 \mathrm{Mo} / \mathrm{Al}_{2} \mathrm{O}_{3}-\mathrm{B}$} & 5 & 44.0 & 39.8 & 9.4 & 7.8 & 40.3 & 1.4 & 1.3 \\
\hline & 15 & 43.2 & 41.3 & 7.6 & 5.9 & 43.1 & 1.0 & 1.1 \\
\hline & 25 & 41.5 & 42.8 & 6.5 & 5.3 & 43.8 & 1.0 & 0.6 \\
\hline & 35 & 40.1 & 43.3 & 5.5 & 4.4 & 45.2 & 1.1 & 0.5 \\
\hline \multirow[t]{4}{*}{$6 \mathrm{Mo} / \mathrm{Al}_{2} \mathrm{O}_{3}-\mathrm{C}$} & 5 & 41.2 & 42.4 & 7.5 & 5.9 & 41.2 & 2.3 & 0.7 \\
\hline & 15 & 38.6 & 42.5 & 4.7 & 4.5 & 45.7 & 1.9 & 0.7 \\
\hline & 25 & 36.6 & 43.0 & 4.0 & 3.8 & 46.6 & 2.0 & 0.6 \\
\hline & 35 & 35.8 & 44.3 & 4.6 & 3.9 & 44.8 & 2.0 & 0.4 \\
\hline \multirow[t]{4}{*}{$6 \mathrm{Mo} / \mathrm{Al}_{2} \mathrm{O}_{3}-\mathrm{D}$} & 5 & 41.4 & 43.6 & 5.4 & 4.5 & 45.0 & 0.9 & 0.6 \\
\hline & 15 & 40.8 & 44.4 & 5.1 & 4.2 & 44.8 & 0.7 & 0.8 \\
\hline & 25 & 36.1 & 43.9 & 3.4 & 2.9 & 48.4 & 0.9 & 0.5 \\
\hline & 35 & 14.9 & 45.1 & 1.7 & 1.3 & 49.1 & 2.2 & 0.6 \\
\hline
\end{tabular}

Reaction conditions: $100^{\circ} \mathrm{C}, 1.0 \mathrm{MPa}, \mathrm{WHSV}=3 \mathrm{~h}^{-1}$. 


\section{Conclusions}

The catalytic performance of a series of Mo-based catalysts in the self-metathesis reaction of 1-butene under various reaction conditions was investigated. The $6 \mathrm{Mo} / \mathrm{Al}_{2} \mathrm{O}_{3}$ catalyst exhibited the best catalytic performance of the examined systems at around $80{ }^{\circ} \mathrm{C}$ and 1.0 MPa with a 1-butene WHSV of $3.0 \mathrm{~h}^{-1}$. Under these conditions, 1-butene conversion was as high as $47 \%$ on the premise of ethene selectivity of $42 \%$. In the complicated reaction network, $\Delta_{\mathrm{r}} G$ of Metathesis I (1-butene $\rightarrow$ ethene + 3-hexene) was much higher than that of Metathesis II (1-butene +2 -butene $\rightarrow$ propene +2 -pentene). Double-bond isomerization of 1-butene was proved as the step determining the target olefin selectivity. An alumina support with large surface area was beneficial for the effective dispersion of Mo species and formation of tetrahedral Mo species. Suitable acidity and Mo dispersion were vital factors that promoted the 1-butene self-metathesis reaction. A high ratio of octahedral Mo species may lead to the rapid deactivation of the $\mathrm{Mo} / \mathrm{Al}_{2} \mathrm{O}_{3}$ catalyst.

\section{References}

[1] S. J. Connon, S. Blechert, Angew. Chem. Int. Ed., 2003, 42, 1900-1923.

[2] S. Lwin, I. E. Wachs, ACS Catal., 2014, 4, 2505-2520.

[3] D. P. Debecker, B. Schimmoeller, M. Stoyanova, C. Poleunis, P. Bertrand, U. Rodemerck, E. M. Gaigneaux, J. Catal., 2011, 277, 154-163.

[4] S. J. Huang, S. L. Liu, W. J. Xin, J. Bai, S. J. Xie, Q. X. Wang, L. Y. Xu, J. Mol. Catal. A, 2005, 226, 61-68.

[5] S. J. Huang, F. C. Chen, S. L. Liu, Q. J. Zhu, X. X. Zhu, W. J. Xin, Z. C. Feng, C. Li, Q. X. Wang, L. Y. Xu, J. Mol. Catal. A, 2007, 267, 224-233.

[6] E. Mazoyer, K. C. Szeto, N. Merle, S. Norsic, O. Boyron, J. M. Basset, M. Taoufik, C. P. Nicholas, J. Catal., 2013, 301, 1-7.

[7] B. A. Zhang, Y. S. Li, Q. S. Lin, D. Jin, J. Mol. Catal. A, 1988, 46, 229-241.
[8] M. Khanmohammadi, Sh. Amani, A. Bagheri Garmarudi, A. Niaei, Chin. J. Catal., 2016, 37, 325-339.

[9] C. X. Qi, Y. X. Wang, X. T. Ding, H. J. Su, Chin. J. Catal., 2016, 37, 1747-1755.

[10] Y. J. Ding, Chin. J. Catal., 2017, 38, 1-4.

[11] S. J. Huang, H. J. Liu, L. Zhang, S. L. Liu, W. J. Xin, X. J. Li, S. J. Xie, L. Y. Xu, Appl. Catal. A, 2011, 404, 113-119.

[12] E. Mazoyer, K. C. Szeto, S. Norsic, A. Garron, J. M. Basset, C. P. Nicholas, M. Taoufik, ACS Catal., 2011, 1, 1643-1646.

[13] L. Harmse, C. van Schalkwyk, E. van Steen, Catal. Lett., 2010, 137, 123-131.

[14] D. P. Debecker, M. Stoyanova, F. Colbeau-Justin, U. Rodemerck, C. Boissiere, E. M. Gaigneaux, C. Sanchez, Angew. Chem. Int. Ed., 2012, 51, 2129-2131.

[15] X. J. Li, W. P. Zhang, S. L. Liu, L. Y. Xu, X. W. Han, X. H. Bao, J. Catal., 2007, 250, 55-66.

[16] S. L. Liu, S. J. Huang, W. J. Xin, J. Bai, S. J. Xie, L. Y. Xu, Catal. Today, 2004, 93-95, 471-476.

[17] A. Ramanathan, J. F. Wu, R. Maheswari, Y. F. Hu, B. Subramaniam, Microporous Mesoporous Mater., 2017, 245, 118-125.

[18] K. Tao, Q. X. Ma, N. Tsubaki, S. H. Zhou, L. Han, J. Mol. Catal. A, 2016, 416, 39-46.

[19] D. R. Hua, S. L. Chen, G. M. Yuan, Y. Z. Wang, Q. F. Zhao, X. L. Wang, B. Fu, Microporous Mesoporous Mater., 2011, 143, 320-325.

[20] R. J. Gartside, M. I. Greene, A. M. Khonsari, L. L. Murrell, US Patent 6683019 B2, 2004.

[21] W. Xu, Z. K. Xie, Y. D. Wang, S. Liu, Z. B. Xu, CN Patent 100408165 C, 2008.

[22] Y. D. Wang, W. Xu, Z. K. Xie, Z. B. Xu, S. Liu, CN Patent 1915938 A, 2007.

[23] C. L. Yaws, Chemical Properties Handbook, McGraw-Hill, New York, 1999, 288-339.

[24] H. J. Liu, S. J. Huang, L. Zhang, S. L. Liu, W. Wang, W. J. Xin, S. J. Xie, L. Y. Xu, Chin. J. Catal., 2008, 29, 513-518.

[25] D. Z. Zhang, X. J. Li, S. L. Liu, S. J. Huang, X. X. Zhu, F. C. Chen, S. J. Xie, L. Y. Xu, Appl. Catal. A, 2012, 439-440, 171-178.

\section{Graphical Abstract}

Chin. J. Catal., 2018, 39: 37-46 doi: 10.1016/S1872-2067(17)62918-8

\section{Self-metathesis of 1-butene to ethene and hexene over molybdenum-based heterogeneous catalysts}

Ce Guo, Xiujie Li*, Xiangxue Zhu, Weifeng Chu, Shenglin Liu, Yuzhong Wang, Peng Zeng, Shujing Guo, Longya $\mathrm{Xu}^{*}$

Dalian Institute of Chemical Physics, Chinese Academy of Sciences;

University of Chinese Academy of Sciences;

China Huanqiu Contracting and Engineering Corporation;

Shaanxi Yanchang Petroleum (Group) Co. Ltd.

A novel route to produce ethene and hexene through self-metathesis of 1-butene over molybdenum-based catalysts was proposed.

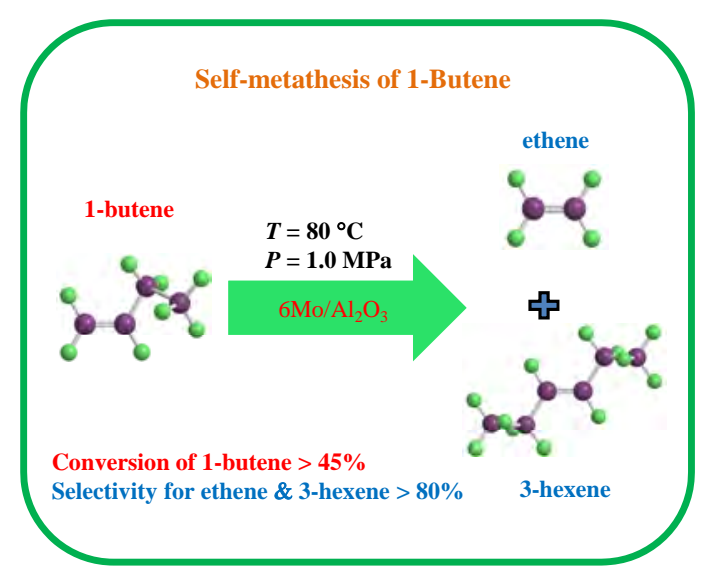


[26] M. C. Abello, M. F. Gomez, O. Ferretti, Appl. Catal. A, 2001, 207, 421-431.

[27] S. Rajagopal, J. A. Marzari, R. Miranda, J. Catal., 1995, 151, 192-203.

[28] X. J. Li, W. P. Zhang, S. L. Liu, S. J. Xie, X. X. Zhu, X. H. Bao, L. Y. Xu, J. Mol. Catal. A, 2009, 313, 38-43.

[29] S. L. Liu, X. J. Li, W. J. Xin, S. J. Xie, P. Zeng, L. X. Zhang, L. Y. Xu, J. Nat. Gas Chem., 2010, 19, 482-486.
[30] X. Li, W. P. Zhang, X. J. Li, S. L. Liu, Prog. Chem., 2008, 20, 1021-1031.

[31] J. Handzlik, J. Ogonowski, J. Stoch, M. Mikołajczyk, P. Michorczyk, Appl. Catal. A, 2006, 312, 213-219.

[32] D. P. Debecker, D. Hauwaert, M. Stoyanova, A. Barkschat, U. Rodemerck, E. M. Gaigneaux, Appl. Catal. A, 2011, 391, 78-85.

[33] G. Xiong, C. Li, Z. C. Feng, P. L. Ying, Q. Xin, J. K. Liu, J. Catal., 1999, $186,234-237$.

\section{高效钼基催化剂上正丁烯自歧化生成乙烯和己烯}

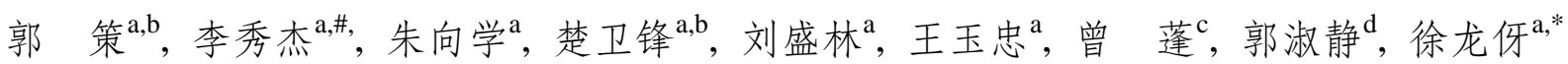

a中国科学院大连化学物理研究所洁净能源国家实验室, 辽宁大连 116023

b中国科学院大学, 北京100049

c中国兾球工程公司辽宁分公司, 辽宁抚顺113006

d陕西延长石油(集团)有限责任公司, 陕西延安 716000

摘要: 烯烃歧化反应(又称烯烃复分解反应)是两分子烯烃通过碳-碳键断裂重排生成新烯烃分子的反应, 自1964年Phillips 公司的Banks等发现以来, 引起了研究者的广泛关注, 且在均相催化体系的发展尤为迅速; 与此同时, 多相烯烃歧化催化剂 因其在分离简单、可循环再生利用方面的优势而在工业界崭露锋芒. 多相烯烃歧化催化剂通常由活性金属组分(Re, Mo, W)分散到大比表面积的多孔载体制备而成. 多相催化剂上烯烃歧化反应主要集中在乙烯和2-丁烯反歧化制丙烯反应, 其 中 $\mathrm{WO}_{3} / \mathrm{SiO}_{2}$ 催化剂先后应用于Phillips公司的Triolefin Process和ABB Lummus公司的OCT工艺, 低温Re系催化剂被法国石 油研究院应用到Meta-4歧化工艺. 同时丙烯歧化也是研究最多的反应, 多数情况下被用作探针反应来研究催化剂的性能.

烯烃歧化反应可以根据市场需求灵活调变产物分布, 为碳四烃类的高效转化利用提供很好的途径. 受国内拉动内需 的政策及下游应用行业强劲需求的影响, 中国液化石油气的产量逐年递增. 2014年我国液化气产量约为2550万吨, 其中仅 有 $39 \%$ 左右用于碳四深加工, 大部分当做燃料直接烧掉. 从组成来看, 液化气中烯烃含量在 $40 \%-50 \%$, 可以转化为高附加 值的乙烯和丙烯进一步利用. 本文重点开发了一条从1-丁烯出发生产乙烯/已烯的反应路线及对应的催化剂. 首先从热力 学角度分析了碳四歧化反应网络中各反应路径发生的难易程度. 在此基础上, 以 $\mathrm{Mo} / \mathrm{Al}_{2} \mathrm{O}_{3}$ 为催化剂考察了 $\mathrm{Mo}$ 负载量和反 应条件对产物分布的影响. 在优化的 $6 \mathrm{Mo}^{-} \mathrm{Al}_{2} \mathrm{O}_{3}$ 催化剂上, $80^{\circ} \mathrm{C}, 1.0 \mathrm{MPa}$ 和丁烯空速 $3 \mathrm{~h}^{-1}$ 的条件下, 产物中乙烯和已烯的 摩尔选择性超过 $85 \%$, 并且在 $48 \mathrm{~h}$ 内保持良好的反应稳定性. 为了进一步探究催化剂结构与反应性能的关系, 系统考察了 催化剂载体差异对Mo物种状态和反应性能的影响. 借助 $\mathrm{N}_{2}$ 吸附, $\mathrm{NH}_{3}$-TPD, Py-IR, $\mathrm{H}_{2}$-TPR, UV-Vis和HRTEM等表征手段, 发现催化剂反应活性与其酸密度直接相关. 催化剂酸量越大, 丁烯转化率越高, 但副反应越多; 载体适宜的酸量和较大的 比表面积更有利于钿物种的分散和四配位钿物种的形成, 促进目标1-丁烯自歧化制乙烯/已烯反应的发生.

关键词: 1-丁烯; 自歧化; 钿; 乙烯; 己烯

收稿日期: 2017-09-11. 接受日期: 2017-09-16. 出版日期: 2018-01-05.

*通讯联系人. 电话/传真: (0411)84379279; 电子信箱: lyxu@dicp.ac.cn

\#通讯联系人. 电话/传真: (0411)84379279; 电子信箱: xiujieli@dicp.ac.cn

基金来源：国家自然科学基金(21773233); 辽宁省自然科学基金(201602740).

本文的电子版全文由Elsevier出版社在ScienceDirect上出版(http://www.sciencedirect.com/science/journal/18722067). 